\title{
Strategic Planning and Its Implications on SMEs in Bangladesh: An Empirical Study
}

\author{
Md. Hafij Ullah ${ }^{1} \&$ Faruk Bhuiyan ${ }^{2}$ \\ ${ }^{1}$ Assistant Professor, Department of Business Administration, International Islamic University \\ Chittagong, BANGLADESH \\ ${ }^{2}$ Lecturer, Department of Business Administration, International Islamic University Chittagong, \\ BANGLADESH
}

\begin{abstract}
Strategic plan is an important integral part and vital factor for long-tern success and sustainable development of any organization and also for SMEs. Without strategic plan an SME may journey towards an imaginary destination. The current study is an endeavor to highlight the present scenario of SMEs in Bangladesh, scope of strategic plan in SMEs, barriers to preparing strategic plan and ways to removal of the barriers and finally implications of strategic plan in SMES in Bangladesh. The paper found that sustainable development of SMEs highly depends on the preparation and implementation of strategic plan in SMEs in Bangladesh and strategic plan has direct impact on the growth of number of employees, volume of capital and return on sales of SMEs.
\end{abstract}

Key Words: Strategic Planning, SME, Implications, Implementation, and Bangladesh.

\section{GEL Classification Code: O20; G32; M13}

\section{INTRODUCTION}

Strategic planning refers to the setting of long-term business goals, and the developing and implementing of the formal plans to achieve these goals. Strategic planning is a vital ingredient in small business development, competitiveness and success (Vicere, 1995). For example: small business that strategically plans are more likely to be those that achieve higher sales growth, higher return on assets, higher profit margins and higher employee growth. Small businesses that strategically plan are also more likely to be those that are innovative, those that achieve international growth and those less likely to fail. It improves the business performance, business decisions and enhances employee commitment (Curtis 1983). Peel and Brigade (1998) have highlighted a strong positive correlation between the success of SME's and the degree of long term planning undertaken.

In the survey of 214 German industrial enterprises Esser et. al. (1985) found that instruments of strategic planning are most frequently applied in the long term of a limited and incorporated company. Their results show a positive correlation between a company's workforce size and the uses of strategic planning activities. Berman, Gordon and Sussmann (1997) argue that enterprises that plan strategically obtain the better financial results. For example: Schwek and Shrader (1993) showed in their meta- analysis that the existence of 
strategic planning is significantly positively correlated with an enterprise's (financial) success. Given all the evidence on the benefits of strategy and planning, most small businesses don't strategically plan. SMEs' are more likely to have short term plans and a non-financial, non-written type of strategy looks to better suit their needs (Stonehouse and Pembereton 2002). In practice the primary focus of small business operators is short term operational rather that long-term strategic issues, and their decision making is generally reactive and intuitive rather than practical and deliberate.

Research into why small businesses generally don't engage in strategic planning has suggested that operators may be hindered or discouraged by "planning barriers" such as; a lack of time, lack of specialized expertise, inadequate knowledge of the planning processes or a reluctance to share strategic plans with employees and external consultants (Robinson and Pearce 1984). O' Regan and Ghobadian indicated a number of general barriers relating to the constraint of strategic planning implementation, such as; communication was inadequate, implantation took longer than expected, a short fall in employee skills, objectives of a strategy were not clearly understood by the staff, ineffective coordination of implementation, unexpected external problems arouse and external factors impacted on implementation. Recently Wang, Walker and Redmond (in press) argued that business ownership motivations are a major reason for why many small businesses do not strategically plan. However, firms with strategic plan are better in position to overcome such implementation barriers. A Wilcoxon test was used to ascertain the difference in the extent to which implementation problems are experienced by both categories of firms with formal plan and firms without formal plan. The results showed that firms with strategic plan are better prepared to overcome the implementation problems than firms without strategic plan. This indicates that formal planning is more likely to enables firms to meet any potential barriers and problems with greater confidence (O Regan N. and Ghobadian A., 2007).

\section{ObJectives Of The Study}

The main objective of the study is to evaluate the importance of strategic plan for SMEs in Bangladesh. To fulfill the main objective, the specific objectives are as stated below:

- To justify the importance for strategic plan for SMEs in Bangladesh.

- To identify the barriers in preparing strategic plan in SMEs in Bangladesh.

- To evaluate the impact/implications of strategic plan in SMEs in Bangladesh.

- To identify the ways to overcome the barriers in preparing strategic plan in SMEs in Bangladesh.

\section{Methodology of the Study}

The study is an exploratory research completed basically based on primary data. Some secondary data was used for showing the SME scenario in Bangladesh. A questionnaire survey was conducted among the owners, managers, and officers of 48 SMEs from different parts of Chittagong on the basis of purposive sampling because the working place of the authors is Chittagong. According to the location of the SMEs, the SMEs under study are from New Market 28 (19.44\%), Halishahar 18 (12.50\%), Chawk Bazar 16 (11.11\%), Sitakunda 13 (9.03\%), Chandgaon 14 (9.72\%), Bahaddar Hat 15 (10.42\%), Agrabad 21 (14.58\%), Chawmohoni 8 (5.56\%), Fawzdarhat 6 (4.17\%), Kumira 5 (3.47\%).

As per the nature of SME business, the frequencies are Restaurant 29 (20.14\%), Poultry, Dairy \& Nursery 22 (15.28\%), Bakery 23 (15.97\%), Ready Made Garments (RMG) 21 (14.58\%), Books and Stationary 16 (11.11\%), Jewelers 33 (22.92\%).

As per the designation, the respondents are Officer 14 (9.72\%), Manager 35 (24.31\%), and 
Owner $95(65.97 \%)$ and the level of education of the respondents is Below SSC 14 (9.72\%), Below HSC 23 (15.97\%), Graduate 38 (26.39\%), and Masters 69 (47.92\%).

The age distribution of SMEs having less than 1 year of age is $11(7.64 \%)$, SMEs having 1-3 years of age is $21(14.58 \%)$, SMEs having 3-6 years of age is $34(23.61 \%)$, SMEs having 6-9 years of age is $29(20.14 \%)$ and SMEs having more than 9 years of age is $49(34.03 \%)$.

The data was collected through in depth interview with the respondents based on structured questionnaire during November and December, 2011. After collection, the data were tabulated and analyzed through percentage, frequency distribution, etc.

\section{LIMITATIONS OF THE STUDY}

The study is a self financed study because of what a small sample size were chosen for the study. Another limitation is $25.69 \%$ of the respondents have very few or no idea about strategic plan as they have no study in this regard because of their poor level of education that is less than HSC.

\section{SME SCENARIOS IN BANGLADESH}

In 2003 the International Consultancy Group (ICG) of the UK, in collaboration with the Micro Industries Development Assistance and Services (MIDAS), conducted the National Private Sector Survey of Enterprises in Bangladesh. The survey results drew the conclusion that there were approximately 6 million Small and Medium Enterprises (SMEs) which included enterprises with up to 100 workers employing a total of 31 million people, equivalent to 40 per cent of the population of the country of age 15 years and above. The survey also found that the industrial structure of SMEs consisted of primarily wholesale and retail trade and repairs (40 per cent), production and sale of agricultural goods (22 percent), services (15 percent), and manufacturing only (14 per cent). Thus the survey brought out the fact that the large untapped potential for expansion in manufacture and production could be exploited (or contributing more significantly to the national economy. Another vital findings of the survey under discussion was that SMEs contributed BDT 741 (\$ 12.5) billion i.e. nearly 25 per cent of the GDP (BDT 2,996 billion) in 2003. It is reflected from this survey that enterprises employing 2-5 workers contribute 51 percent share of the total SME contribution to the economy, followed by 26 percent by those having only one worker and 10 per cent by those having 6-10 workers. For LDCs like Bangladesh, SMEs are a highly cost-effective route for industrial development. It is observed from Table-1 that micro enterprises run by up to 10 workers contribute the most which is $86 \%$ of the total contribution from SMEs to GDP of Bangladesh. It is also observed that micro enterprises run by more than 21 workers contribute about 7\% of total contribution from SME to GDP of Bangladesh.

Table 1: Contribution of SMEs in the GDP of Bangladesh

\begin{tabular}{|c|c|c|}
\hline Number of Workers & $\begin{array}{c}\text { Total Contribution to } \\
\text { GDP (Taka) }\end{array}$ & \% of total Contribution \\
\hline $0-1$ & 193996555714 & 26 \\
\hline $2-5$ & 379663897358 & 51 \\
\hline $6-10$ & 73120983681 & 10 \\
\hline $11-20$ & 45183240157 & 6 \\
\hline $21-50$ & 33960498076 & 5 \\
\hline $51-100$ & 15138922373 & 2 \\
\hline Total & 741064097360 & 100 \\
\hline
\end{tabular}

Source: ICG/MIDAS Survey, 2003. Note: US $\$ 1=B D T 69.0$ 
Table-2 provides the information regarding sector wise contribution of SMEs to GDP. It is reflected from the table that manufacturing sector contributes the highest contribution in GDP i.e., $38 \%$. It is also observed from the table that agriculture contributes $24 \%$, wholesale and retail sector contribute more than $23 \%$ in the GDP of Bangladesh.

Table-2 Sector wise contribution of SME in GDP of Bangladesh (Taka)

\begin{tabular}{|l|c|c|}
\hline \multicolumn{1}{|c|}{ Sector } & $\begin{array}{c}\text { Total Contribution } \\
\text { to GDP (Taka) }\end{array}$ & $\begin{array}{c}\text { Percentage of Total } \\
\text { Contribution }\end{array}$ \\
\hline Agriculture & 17772963763 & $24 \%$ \\
\hline Fishing & 32872674464 & $4 \%$ \\
\hline Manufacturing & 282344700575 & $38 \%$ \\
\hline Construction & 7196460200 & $1 \%$ \\
\hline Wholesale and Retail trade and Repairs & 171335861390 & $23 \%$ \\
\hline Hotels and Restaurants & 28599263975 & $3 \%$ \\
\hline Transport, Storage and Communication & 8950171356 & $1 \%$ \\
\hline Real state, Renting and Business activities & 13771436794 & $2 \%$ \\
\hline Education & 151808506 & $1 \%$ \\
\hline Health and Social Work & 2743049893 & $1 \%$ \\
\hline Other Service activities & 15632094785 & $2 \%$ \\
\hline Total & 741327159609 & $100 \%$ \\
\hline
\end{tabular}

Source: ICG/MIDAS Survey, 2004, Note: US \$ 1 = BDT 69.00

Small and Medium Scale play an important role in the socioeconomic advancement of a country through decentralization, diversification of industries, innovation of new products and services, creation of new entrepreneurs, employment generation, utilization of natural resources and in overall, raising contribution to the GDP of the country. The contribution of the small and medium scale industries in GDP of Bangladesh are stated below:

Table-3: Contribution of Small scale industries in GDP of Bangladesh (at constant market prices)

\begin{tabular}{|l|l|l|l|l|l|l|}
\hline & $\mathbf{2 0 0 4 - 0 5}$ & $\mathbf{2 0 0 5 - 0 6}$ & $\mathbf{2 0 0 6 - 0 7}$ & $\mathbf{2 0 0 7 - 0 8}$ & $\mathbf{2 0 0 8 - 0 9}$ & $\mathbf{2 0 0 9 - 1 0}$ \\
\hline GDP of Small scale Industries (Million Tk.) & 124085 & 135515 & 148651 & 159200 & 170189 & 180911 \\
\hline Total GDP of Bangladesh (Million Tk.) & 2669740 & 2846726 & 3029709 & 3217260 & 3401968 & 3600465 \\
\hline$\%$ of GDP contribution of SSIs & 4.85 & 4.94 & 5.08 & 5.14 & 5.18 & 5.20 \\
\hline$\%$ of Growth Rate of GDP of SSIs & 7.93 & 9.21 & 9.69 & 7.10 & 6.90 & 6.30 \\
\hline
\end{tabular}

Source: Statistical Year Book 2010, National Income Section, BBS.

Table-4 shows the growth pattern of SME. It is observed that during 2001-2002 to 2004-2005 in every financial year the growth rate of SME is about 7\%. In 2005-2006 the growth rate was $9.21 \%$. The highest growth was in 2006-2007 i.e., $10.28 \%$.

Table-4 Growth Pattern of SMEs in Bangladesh

\begin{tabular}{|c|c|}
\hline Year & Growth Percentage of Small Enterprises \\
\hline $2001-02$ & 7.69 \\
\hline $2002-03$ & 7.21 \\
\hline $2003-04$ & 7.45 \\
\hline $2004-05$ & 7.93 \\
\hline $2005-06$ & 9.21 \\
\hline $2006-07$ & 10.28 \\
\hline
\end{tabular}

Source: Bangladesh Economic Review 2006-2007. 
Table-5 shows the growth pattern of manufacturing sector. It is observed that the average growth during 1972 to 2005 was 6.4\%. During 2001-2002 to 2006-2007 the highest growth was in year 2006-07 i.e., $11.19 \%$. It is also observed that during 2002-2003 to 2005-2006 in every financial year the growth of manufacturing sector was more than $6 \%$.

Table-5: Growth Pattern of Manufacturing Sector

\begin{tabular}{|c|c|}
\hline Year & Growth Percentage of Manufacturing Sector \\
\hline $1972-2000$ & 6.4 \\
\hline $2001-02$ & 5.48 \\
\hline $2002-03$ & 6.75 \\
\hline $2003-04$ & 7.10 \\
\hline $2004-05$ & 8.19 \\
\hline $2005-06$ & 10.77 \\
\hline $2006-07$ & 11.19 \\
\hline 2015 & Expected Growth 15 \\
\hline
\end{tabular}

Source: Bangladesh Economic Review 2006-07.

Table-6 shows that, Total SME loans increased by 35.93 percent at the end of December, 2010 as compared at the end of December, 2009 and 16.64 percent at the end of December, 2011 as compared at the end of December, 2010. Institutional category-wise SME loans increased at the end of December, 2010 in private banks (52.03\%), specialized banks $(28.09 \%)$, foreign banks $(19.30 \%)$, state owned banks (17.34\%) and non-bank financial institutions $(27.91 \%)$ as compared to December, 2009 and at the end of December, 2011 in private banks (23.91\%), specialized banks (12.27\%), foreign banks (10.51\%), state owned banks (6.43\%) and non-bank financial institutions (4.17\%) as compared to December, 2010.

Table-6: Outstanding position of SME loans as compare to total loans (Tk. In Crore)

\begin{tabular}{|c|c|c|c|c|c|c|c|}
\hline & $\begin{array}{l}\text { Types of } \\
\text { Loans }\end{array}$ & $\begin{array}{c}\text { State Owned } \\
\text { Banks } \\
\end{array}$ & $\begin{array}{c}\text { Private } \\
\text { Banks }\end{array}$ & $\begin{array}{c}\text { Foreign } \\
\text { Banks }\end{array}$ & $\begin{array}{c}\text { Specialized } \\
\text { Banks }\end{array}$ & $\begin{array}{c}\text { Non-Bank } \\
\text { FIs }\end{array}$ & Total \\
\hline Dec, & Total Loans & 54931.53 & 157471.37 & 15324.52 & 16250.25 & 12948.61 & 256926.28 \\
\hline 2009 & $\begin{array}{l}\text { SME Loans } \\
\text { Percentage }\end{array}$ & $\begin{array}{c}18612.29 \\
(33.9)\end{array}$ & $\begin{array}{c}25707.55 \\
(16.3)\end{array}$ & $\begin{array}{c}1582.21 \\
(10.3)\end{array}$ & $\begin{array}{c}3315.82 \\
(20.4)\end{array}$ & $\begin{array}{c}1929.71 \\
(14.9)\end{array}$ & $\begin{array}{c}51147.59 \\
(19.9)\end{array}$ \\
\hline Dec, & Total Loans & 68702.48 & 204442.22 & 18486.44 & 20578.15 & 17741.02 & 329950.31 \\
\hline 2010 & $\begin{array}{l}\text { SME Loans } \\
\text { Percentage }\end{array}$ & $\begin{array}{c}21839.54 \\
(31.79) \\
\end{array}$ & $\begin{array}{c}39083.85 \\
(19.12) \\
\end{array}$ & $\begin{array}{c}1887.54 \\
(10.21) \\
\end{array}$ & $\begin{array}{c}4247.31 \\
(20.64) \\
\end{array}$ & $\begin{array}{c}2468.34 \\
(13.91) \\
\end{array}$ & $\begin{array}{c}69526.58 \\
(21.07) \\
\end{array}$ \\
\hline Dec, & Total Loans & 81405.37 & 244335.67 & 21165.99 & 22994.08 & 20826.99 & 390728.10 \\
\hline $2011 p$ & $\begin{array}{l}\text { SME Loans } \\
\text { Percentage }\end{array}$ & $\begin{array}{c}23244.5 \\
(28.55)\end{array}$ & $\begin{array}{c}48429.16 \\
(19.82)\end{array}$ & $\begin{array}{c}2085.89 \\
(9.85)\end{array}$ & $\begin{array}{l}4768.3 \\
(20.74)\end{array}$ & $\begin{array}{c}2571.38 \\
(12.35)\end{array}$ & $\begin{array}{c}81099.23 \\
(20.76)\end{array}$ \\
\hline \multicolumn{2}{|c|}{$\begin{array}{c}\% \text { change of SME loans at } \\
\text { the end of December, } 2010 \\
\text { over December, } 2009 .\end{array}$} & 17.34 & 52.03 & 19.30 & 28.09 & 27.91 & 35.93 \\
\hline \multicolumn{2}{|c|}{$\begin{array}{c}\text { \% change of SME loans at } \\
\text { the end of December, } 2011 \\
\text { over December, } 2010 .\end{array}$} & 6.43 & 23.91 & 10.51 & 12.27 & 4.17 & 16.64 \\
\hline
\end{tabular}

Source: SME \& Special Programs Department, Bangladesh Bank.

Note: Figures in brackets indicate SME loans as percentage of total loans. $\mathrm{P}=$ provisional

Table-7 depicts the credit disbursement strategy being focused by the different categories of financial institutions while disbursing loans to SME sector. NBFIs become the prominent 
players in disbursing loan strategy to the much desired SME sector constituting 35.5 percent of their total loan portfolio disbursement. The rest has been followed by SOBs and PCBs consisting of $28.7 \%$ and $22.1 \%$ respectively of their own loan disbursement portfolio.

Table 7: Loan disbursement to SME as \% of total disbursement by Categories of Financial Institutions

\begin{tabular}{|c|c|c|}
\hline SL No. & Category of Financial Institution (FI) & Loan disbursement to SME as \% \\
\hline 01 & NBFIs & $32.5 \%$ \\
\hline 02 & SOBs & $28.7 \%$ \\
\hline 03 & PCBs & $22.1 \%$ \\
\hline 04 & SBs & $13.5 \%$ \\
\hline 05 & FCBs & $7.7 \%$ \\
\hline & Total & $100 \%$ \\
\hline
\end{tabular}

Source: SMESP Department, BB, 31st Dec. 2009.

Of the total loan disbursed to SME sector in the last quarter of 2009, around $50 \%$ went to Small Enterprises (SE). Table-8 shows the relative contribution of different categories of participating FIs in terms of disbursement to SE (18.1\% of loan disbursement portfolio), while SOBs and PCBs were the subsequent successor.

Table-8: Loan disbursement to SE as \% of total Disbursement by FIs

\begin{tabular}{|c|c|}
\hline Categories of FIs & Loan Disbursement to SE as \% of total disbursement \\
\hline SOBs & $17.3 \%$ \\
\hline PCBs & 10.2 \\
\hline SBs & 7.8 \\
\hline FCBs & 3.8 \\
\hline NBFIs & 18.1 \\
\hline
\end{tabular}

Source: Computed from data of SMESP Department, BB, 31st Dec. 2009.

\section{6: THE SCOPE OF STRATEGIC PLANNING IN SMES}

For the German-speaking countries, the following picture concerning strategic planning in SMEs emerges: In their survey of 214 German industrial enterprises Esser et al. (1985) found that instruments of strategic planning are most frequently applied in the legal form of a limited $(\mathrm{GmbH})$ and incorporated $(\mathrm{AG})$ company. Additionally, their results show a positive correlation between a company's workforce size and the use of strategic planning activities. Based on an analysis of 1461 German industrial enterprises, Scholz (1991) identified a rate of $73 \%$ of SMEs indicating to plan strategically. In contrast, the result from Austria and Switzerland look rather disillusioning. Kropfberger (1986) revealed in a survey of 161 medium sized enterprises in Austria that nearly half of the enterprises under study only plan on a short term basis and that almost one third does not have any sales planning at all. Similarly, Frohlich and Pichler ?(1988) found that almost one quarter of the 107 enterprises they investigated did not apply any planning, about one third only used short term plan and another third long term planning and only $12 \%$ used strategic planning. An almost identical picture shows up in Switzerland, where Haake (1987) surveyed 127 SMEs from different industries: $27 \%$ of the enterprises applied no written planning, $31.4 \%$ only short term planning, $26.9 \%$ long-term planning, and finally $13.7 \%$ strategic planning.

Hofner, Kirsch and Wieselhuber (1985) surveyed on 214 SMEs with less than 500 employees from Germany. The result showed that $26.9 \%$ of SMEs plan strategically. Kupper and 
Bronner (1995) conducted a survey on 240 SMEs from German. The result found that almost no long-term plan is prepared. Naffziger and Mueller (1999) surveyed on 71 SMEs with less than 500 employees from US and found that $46.5 \%$ of the enterprises do not have written Vision or Mission statement. Litner (2001) conducted a survey on 100 SMEs from Austria and got $62 \%$ of the enterprises have a written corporate policy. Gibson and Cassar (2002) surveyed on 3554 SMEs from Australia and found that more than 30\% of the enterprises apply documented planning, however, only 50\% of those prepare on an annual basis, larger firms plan more than smaller ones. Shane (2003) researched on 211 SMEs from Sweden. The result showed that strategic planning increases the degree of product development, the degree of corporate organization and the probability of survival of new ventures.

A study was conducted by Elbanna (2007) in Egypt and found that $35.8 \%$ of the organizations in the sample do not have written strategic plans. A small number of studies of strategic in the Middle East have been undertaken. The picture is less clear in relation to strategic implementation than it is in relation to formulation. Two studies of strategic planning in Egypt have not examined implementation issues (Elbanna, 2007; 2008). In the case of Turkey, there is limited evidence that firms have greater commitment to strategy formulation than strategy implementation or evaluation (Glaister and Flashaw, 1999).

\section{FINDINGS OF THE STUDY}

We have conducted a survey on the owners, managers, and officers of 48 SMEs from Chittagong, Bangladesh and found that although most of the respondents $(89.58 \%)$ believe that long-term planning is important for their success but actually $81.2 \%$ of SMEs prepare such plan.

Table-9: Opinion of the respondents' importance and preparation of L/T plan

\begin{tabular}{|c|c|c|c|c|c|}
\hline \multicolumn{2}{|c|}{ Importance of long-term plan for SMEs: } & \multicolumn{3}{c|}{ Prepare long-term plan for SMEs } \\
\hline Opinion & No. of SMEs & Percentage & Opinion & No. of SMEs & Percentage \\
\hline Yes & 129 & $89.58 \%$ & Yes & 117 & $81.25 \%$ \\
\hline No & 15 & $10.42 \%$ & No & 27 & $18.75 \%$ \\
\hline Total & 144 & $100 \%$ & Total & 144 & $100 \%$ \\
\hline
\end{tabular}

Source: Own survey on SMEs during November-December, 2011.

From the table-9, it is also seen that only $10.42 \%$ of the respondents do not give importance on long-term plan for them but $18.75 \%$ of the do not prepare strategic plan for SMEs. Therefore, $8.33 \%$ of the SMEs do not prepare long-term plan though they admit the importance of long-term plan because of some barriers to strategic plan.

\section{StRATEGiC PLAN AND ITS BENEFITS}

Literature review reveals that preparation of strategic plan is important and beneficial for SMEs. The respondents of our survey also identified different benefits of preparing strategic plan in SMEs in Bangladesh. The responses are listed in the following frequency table.

Table-10: Opinion of the respondents on the benefits of Strategic plan in SMEs

\begin{tabular}{|l|c|c|}
\hline \multicolumn{1}{|c|}{ Benefits } & Frequency & Percentage \\
\hline Higher sales growth & 132 & 91.67 \\
\hline Higher return on assets & 71 & 49.31 \\
\hline igher margin or profit & 83 & 57.64 \\
\hline Higher employee growth & 52 & 36.11 \\
\hline
\end{tabular}




\begin{tabular}{|l|c|c|}
\hline Development and implementation of plan & 65 & 45.14 \\
\hline Sustainable development (avoid failure) & 87 & 60.42 \\
\hline Efficient in competition & 103 & 71.53 \\
\hline International growth & 57 & 39.58 \\
\hline Others: Customer Satisfaction & 7 & 4.86 \\
\hline
\end{tabular}

Source: Own survey on SMEs during November-December, 2011.

As per the opinion of the respondents, SMEs with strategic plan can exploit the benefits of Higher sales growth (91.67\%), Efficient in competition (71.53\%), Sustainable development (avoid failure) (60.42\%), Higher margin or profit (57.64\%), Higher return on assets $(49.31 \%)$, Development and implementation of plan (45.14\%), International growth $(39.58 \%)$, Higher employee growth (36.11\%), and Customer Satisfaction (4.86\%).

\section{BARRIERS IN PREPARING STRATEGIC PLAN IN SMES IN BANGLADESH}

Kropfberger (1986) revealed in a survey of 161 medium-sized enterprises in Australia that nearly half of the enterprises under study only plan on a short term basis and that almost one-third does not have any sales planning at all. In Switzerland, Haake (1987) surveyed 127 SMEs from different industries: $27.9 \%$ of the enterprises applied no written planning, $31.4 \%$ only short term planning, $26.9 \%$ long-term planning and finally $13.7 \%$ strategic planning. Similarly, Frohlich and Pichler (1988) found that almost one-quarter of the 107 enterprises they investigated, about one-third only used short term and another one third long term planning and only $12 \%$ used strategic planning.

Due to the well accepted view that strategies limit an SME's scope of activity too much thereby reducing its flexibility, many SMEs are still lacking written strategic plans (Pleitner, 1986). Scharpe, 1992; Robinson \& Pearce, 1984 identified other reasons why SMEs refuse to engage in formal strategic planning, such as insufficient knowledge, distrust, rejection of external assistance, tradition-based thinking, fear of radical change, high cost, and lack of time or management over load. The degree of an entrepreneur's orientation seems to be a key factor for strategic focus of the enterprises (Mazzarol, 2003).

From our survey, it is found that $18.75 \%$ of SMEs do not prepare long term plan. As a result we had a question on them to explore the barriers associated with not preparing long term plan. The results of the responses are listed in the following frequency table:

Table-11: Opinion regarding reasons of not preparing strategic plan in SMEs

\begin{tabular}{|l|c|c|}
\hline \multicolumn{1}{|c|}{ Reasons } & Frequency & Percentage \\
\hline Lack of specialized expertise & 7 & 25.93 \\
\hline Inadequate knowledge of planning process & 8 & 29.63 \\
\hline Size of business & 4 & 14.81 \\
\hline Environmental uncertainty & 3 & 11.11 \\
\hline Type of industry & 5 & 18.52 \\
\hline Total & 27 & 100 \\
\hline
\end{tabular}

Source: Own survey on SMEs during November-December, 2011.

From the study we can conclude that SMEs do not prepare long term or strategic plan because of lack of specialized expertise $(25.93 \%)$, inadequate knowledge of planning process $(29.63 \%)$, type of industry $(18.52 \%)$ and Size of business $(14.81 \%)$. 


\section{ReMOVAL OF BARRIERS TO STRATEGIC PLAN}

It is not only important to identify the barriers to strategic plan but also important to identify the appropriate way to remove those barriers. As per the opinion of the respondents the following ways may help SMEs in overcoming the barriers to strategic plan:

Table-12: Opinion regarding means of overcoming barriers to strategic plan

\begin{tabular}{|l|c|c|}
\hline Means of overcoming the barriers & Frequency & Percentage \\
\hline To make realization of its importance & 11 & 40.74 \\
\hline Providing training to existing employees & 8 & 29.63 \\
\hline Employing expert employee & 5 & 18.52 \\
\hline Govt. rules or incentives & 3 & 11.11 \\
\hline Total & 27 & 100 \\
\hline
\end{tabular}

Source: Own survey on SMEs during November-December, 2011.

From the table-12, we can list the means of overcoming the barriers as per priority as to realize the importance of strategic planning $(40.74 \%)$, ensure proper training facilities to existing employees on planning process (29.63\%), ensure the employment of expert employees $(18.52 \%)$ and finally formulation of Government rules favorable for preparation of long term plan $(11.11 \%)$.

\section{IMPLICATIONS OF STRATEGIC PLANNING IN SMES IN BANGLADESH}

The existence of strategic planning is significantly positively correlated with an enterprise's (financial) success (Robinson \& Pearce, 1984; Bracker and Pearson, 1986; Bracker et. al. 1988; Schwerk and Shrader, 1993). Matthews and Scott (1995) found that planning activities can help to reduce the level of uncertainty in the company. Berman, Gordon and Sussmann (1997) argued that enterprises that plan strategically obtain better financial results. Delmar and Shane (2003) found in a longitudinal analysis that new ventures conducting formal strategic planning have higher survival rates.

Armstrong (1982) reviewed 12 strategic planning and performance studies and found that strategic planning was enhancing overall performance. In a review of 26 studies of small business, Schwerk and Shrander (1993) found a positive relationship overall between strategic planning and performance. Fossen et. al. (2006) in a review of 85 studies found that strategic planning had a small but significant relationship with performance.

In this study, it has been tried to explore the impact of strategic planning on the overall performance of organization based on three factors: change in number of employees, change in volume of capital and change in return on sales.

\section{1: No. of employees and Strategic Plan}

From the survey of 144 SMEs, it was found that 117 of the SMEs prepare strategic plan out of which number of employees increased in 93 SMEs but not increased in 24 SMEs. On the other hand, 27 SMEs do not prepare strategic plan of which number of employees increased in 13 SMEs but not increased in 14 SMEs. Chi-Square test was used to justify whether there is any significant implications of strategic plan on number of employees of SMEs in Bangladesh. 
Table No. 13: No. of employees and Strategic Plan

\begin{tabular}{|c|c|c|c|}
\hline & Increase No. of Employees & Not Increase No. of Employees & Total \\
\hline Prepare SP & 93 & 24 & 117 \\
\hline Don't Prepare SP & 13 & 14 & 27 \\
\hline Total & 106 & 38 & 144 \\
\hline
\end{tabular}

Source: Own survey on SMEs during November-December, 2011.

Assuming a null hypothesis that there is no implication of strategic plan on number of employees of SMEs in Bangladesh, the calculated value of Chi-square is 11.10992 and at 5\% level of significance and degree of freedom 1, the table value is 3.841. Therefore, the null hypothesis is rejected which signifies that the preparation of strategic plan affect the number of employees of SMEs in Bangladesh. That is, the SMEs which prepare strategic plan can increase the number of employees to increase the overall performance of SMEs.

Table No. 14: Change in No. of employees before and after preparing strategic plan

\begin{tabular}{|c|c|c|c|c|c|}
\hline \multirow{2}{*}{$\begin{array}{c}\text { No. of } \\
\text { employees }\end{array}$} & \multicolumn{2}{|c|}{ Before Strategic Plan } & \multicolumn{2}{|c|}{ After Strategic Plan } & Change in \\
\cline { 2 - 5 } & $\begin{array}{c}\text { No. of } \\
\text { SMEs }\end{array}$ & $\begin{array}{c}\text { Percen } \\
\text { tage }\end{array}$ & $\begin{array}{c}\text { No. of } \\
\text { SMEs }\end{array}$ & $\begin{array}{c}\text { Percen } \\
\text { tage }\end{array}$ & percentage \\
\hline $1-24$ & 97 & 82.91 & 61 & 52.14 & -30.77 \\
\hline $25-49$ & 17 & 14.53 & 26 & 22.22 & 7.69 \\
\hline $50-74$ & 3 & 2.56 & 17 & 14.53 & 11.97 \\
\hline $75-99$ & 0 & 0 & 13 & 11.11 & 11.11 \\
\hline Total & 117 & 100 & 117 & 100 & - \\
\hline
\end{tabular}

Source: Own survey on SMEs during November-December, 2011.

From the above table it is clear that $82.91 \%$ of the SMEs had 1-24 employees before preparing strategic plan but after preparing strategic plan the percentage reduced to only $52.14 \%$, that is, $30.77 \%$ of the SMEs could improve their position, and specifically $7.69 \%$ SMEs improved number of employees to 25-49, 11.97\% SMEs improved number of employees to 50-74, and $11.11 \%$ SMEs improved number of employees to 75-99. Therefore, it can be said that SMEs could increase their volume of activities because of preparing long-term plan for which reason SMEs required to increase their number of employees.

\section{2: The Volume of Capital AND Strategic PLAN}

From the survey of 144 SMEs, it was found that 117 of the SMEs prepare strategic plan out of which volume of capital increased in 92 SMEs but not increased in 25 SMEs. On the other hand, 27 SMEs do not prepare strategic plan of which volume of capital increased in 16 SMEs but not increased in 11 SMEs. Chi-Square test was used to justify whether there is any significant implications of strategic plan on volume of capital of SMEs in Bangladesh.

Table No. 15: The volume of capital and Strategic Plan

\begin{tabular}{|c|c|c|c|}
\hline & Increase Volume of Capital & Not Increase Volume of Capital & Total \\
\hline Prepare SP & 92 & 25 & 117 \\
\hline Don't Prepare SP & 16 & 11 & 27 \\
\hline Total & 108 & 36 & 144 \\
\hline
\end{tabular}

Source: Own survey on SMEs during November-December, 2011. 
Assuming a null hypothesis that there is no implication of strategic plan on volume of capital of SMEs in Bangladesh, the calculated value of Chi-square is 4.391263 and at 5\% level of significance and degree of freedom 1, the table value is 3.841. Therefore, the null hypothesis is rejected which signifies that the preparation of strategic plan affect the volume of capital of SMEs in Bangladesh. That is, the SMEs which prepare strategic plan can increase the volume of capital through additional investment and earnings profit from operations to expand the business of SMEs.

Table No. 16: Change in volume of capital before and after preparing strategic plan

\begin{tabular}{|c|c|c|c|c|c|}
\hline \multirow{2}{*}{ Volume of capital } & \multicolumn{2}{|c|}{ Before Strategic Plan } & \multicolumn{2}{c|}{ After Strategic Plan } & \multirow{2}{*}{$\begin{array}{c}\text { Change in } \\
\text { percentage }\end{array}$} \\
\cline { 2 - 5 } & No. of SMEs & Percentage & No. of SMEs & Percentage & -24.79 \\
\hline Less than 2 Crores & 93 & 79.49 & 64 & 54.70 & 4.27 \\
\hline 2-4 Crores & 17 & 14.53 & 22 & 18.80 & 12.82 \\
\hline 4-6 Crores & 4 & 3.42 & 19 & 16.24 & 7.70 \\
\hline 6-10 Crores & 3 & 2.56 & 12 & 10.26 & - \\
\hline Total & 117 & 100 & 117 & 100 & - \\
\hline
\end{tabular}

Source: Own survey on SMEs during November-December, 2011.

From table no. 16, it can be observed that $79.49 \%$ of the SMEs had capital less than 2 crores before preparing strategic plan but after preparing strategic plan the percentage reduced to only $54.70 \%$, that is, the capital of $24.79 \%$ SMEs increases from 2 Crores to the next levels, and specifically $4.27 \%$ SMEs increased to $2-4$ crores, $12.82 \%$ SMEs increased to $4-6$ crores and 7.70\% SMEs increased to 6-10 crores. Therefore, it can be said that SMEs could increase their volume of activities because of preparing long-term plan for which reason SMEs required to increase their volume of capital.

\section{3: RetURn On SALES AND StRategic PLAN}

From the survey of 144 SMEs, it was found that 117 of the SMEs prepare strategic plan out of which return on sales increased in 88 SMEs but not increased in 29 SMEs. On the other hand, 27 SMEs do not prepare strategic plan of which return on sales increased in 10 SMEs but not increased in 17 SMEs. Chi-Square test was used to justify whether there is any significant implications of strategic plan on return on sales of SMEs in Bangladesh.

Table No. 17: Return on sales and Strategic Plan

\begin{tabular}{|c|c|c|c|}
\hline & $\begin{array}{c}\text { Increase Return } \\
\text { on Sales }\end{array}$ & $\begin{array}{c}\text { Not Increase } \\
\text { Return on Sales }\end{array}$ & Total \\
\hline Prepare SP & 88 & 29 & 117 \\
\hline Don't Prepare SP & 10 & 17 & 27 \\
\hline Total & 98 & 46 & 144 \\
\hline
\end{tabular}

Source: Own survey on SMEs during November-December, 2011.

Assuming a null hypothesis that there is no implication of strategic plan on return on sales of SMEs in Bangladesh, the calculated value of Chi-square is 14.71878 and at $5 \%$ level of significance and degree of freedom 1 , the table value is 3.841 . Therefore, the null hypothesis is rejected which signifies that the preparation of strategic plan affect the return on sales of SMEs in Bangladesh. That is, the SMEs which prepare strategic plan can increase return on sales and increase the overall performance of SMEs. 
Table No. 18: Change in return on sales \% for preparing strategic plan in SMEs

\begin{tabular}{|c|c|c|c|c|c|}
\hline \multirow{2}{*}{$\begin{array}{c}\text { Return on } \\
\text { sales } \%\end{array}$} & \multicolumn{2}{|c|}{ Before Strategic Plan } & \multicolumn{2}{|c|}{ After Strategic Plan } & \multirow{2}{*}{$\begin{array}{c}\text { Change in } \\
\text { percentage }\end{array}$} \\
\cline { 2 - 5 } & No. of SMEs & Percentage & No. of SMEs & Percentage & -14.53 \\
\hline Below $10 \%$ & 22 & 18.80 & 5 & 4.27 & -24.79 \\
\hline $10 \%-15 \%$ & 41 & 35.04 & 12 & 10.26 & -5.98 \\
\hline $15 \%-20 \%$ & 34 & 29.06 & 27 & 23.08 & 9.40 \\
\hline $20 \%-25 \%$ & 10 & 8.55 & 21 & 17.95 & 15.38 \\
\hline $25 \%-30 \%$ & 4 & 3.42 & 22 & 18.80 & 11.11 \\
\hline $30 \%-35 \%$ & 6 & 5.13 & 19 & 16.24 & 9.40 \\
\hline Above 35\% & 0 & 0 & 11 & 9.40 & - \\
\hline Total & 117 & 100 & 117 & 100 & \\
\hline
\end{tabular}

Source: Own survey on SMEs during November-December, 2011.

From the table no. 18 , it can be observed that $18.80 \%$ of the SMEs earned return on sales at less than $10 \%$ before preparing strategic plan but after preparing strategic plan the percentage reduced to $4.27 \%$, that is, the return on sales of $14.53 \%$ SMEs increases from less than $10 \%$ to the next levels and $35.04 \%$ of the SMEs earned return on sales at $10 \%-15 \%$ before preparing strategic plan but after preparing strategic plan the percentage reduced to $10.26 \%$, that is, the return on sales of $24.79 \%$ SMEs increases from $10 \%-15 \%$ to the next levels, and the return on sales of $5.98 \%$ SMEs increases from $15 \%-20 \%$ to the next levels, specifically $9.40 \%$ SMEs increased to 20\%-25\%, 15.38\% SMEs increased to 25\%-30\%, 11.11\% SMEs increased to $30 \%-35 \%$ and $9.40 \%$ SMEs increased to more than $35 \%$. Therefore, it can be said that SMEs could increase their volume of activities because of preparing long-term plan for which reason SMEs could increase their return on sales in percentage.

Hence, based on literature review and our experiment, it may be said that the SMEs having strategic plan own higher amount of capital, more employees and achieve higher returns on sales than before preparation of strategic plan.

\section{POLICY IMPLICATIONS}

Among others the major policy implications of this research are as follows:

- Owners, managers and executives of the SMEs are expected to get motivation for formulating and implementing strategic plan for their SMEs.

- Government and different regulatory bodies would expect to prepare guidelines to inspire the SMEs in this regard.

- The researchers may get ideas for more comprehensive studies relating strategic planning in SMEs.

\section{CONCLUSION}

Finally it can be said that the regulatory bodies especially Government should provide support and motivate the SMEs in preparation of strategic plan because it may help the SMEs in getting long-term success and sustainable development.

\section{REFERENCES:}

Armstrong J. (1982). The value of formal planning for strategic decisions: review of empirical research. Strategic Management Journal 3(3): 197-211. 
Berman, J.A., Gordon, D.D. and Sussmann, G. (1997) 'A study to determine the benefits small business firms derive from sophisticated planning versus less sophisticated types of planning', Journal of Business and Economic Studies, 3(3): 1-11.

Bracker, J.S., Keats, B.W. and Pearson, J.N. (1988) ‘Planning and financial performance among small firms in a growth industry', Strategic Management Journal, 9: 591-603.

Bracker, J.S. and Pearson, J.N. (1986) 'Planning and financial performance of small mature firms', Strategic Management Journal, 7: 503-22.

Brouthers, K. D., Andriessen, F., \& Nicolaes, I. (1998). Driving blind: Strategic decision making in small companies. Long Range Planning, 31(1), 130-138.

Carland, J. C., \& Carland, J. W. (2003, 5-8 Mar). A model of entrepreneurial planning and its effect on performance. Paper presented at the ASBE Annual Conference - Building Bridges to the Future, Houston, Texas.

Delmar, F. and Shane, S. (2003) 'Does business planning facilitate the development of new ventures?', Strategic Management Journal, 24: 1165-85.

Elbanna S. (2007). The nature and practice of strategic planning in Egypt. Strategic Change 16: 227-243.

Elbanna S. (2008). Planning and participation as determinants of strategic planning effectiveness: evidence from the Arabic context. Management Decision 46 (5): 779-796.

Elbanna S, \& Child J. (2007a). The influence of decision, environmental and firm characteristics on the rationality of strategic decision making. Journal of Management Studies 44 (4): 561-591.

Elbanna S, \& Child J. (2007b). Influences on strategic decision effectiveness: development and test of an integrative model. Strategic Management Journal 28: 431-453.

Esser, W.M., Höfner, K., Kirsch, W. and Wieselhuber, N. (1985) 'Der Stand derstrategischen Unternehmensführung in der Bundesrepublik Deutschland und West-Berlin', in W. Trux, G. Müller-Stewens and W. Kirsch (eds.) Das Management strategischer Programme, vol. 2, München: Kirsch, 495-568.

Fossen R, Rothstein H, Korn H. 2006. Thirty-five years of strategic planning and performance research: a meta analysis. Academy of Management Best Conference Paper, BPS, M1.

Frohlich, E. and Pichler, J.H. (1988) Werte und Typen mittelstandischer Unternehmer, Berlin: Duncker \& Humblot.

Gibson, B. and Cassar, G. (2002) 'Planning behavior variables in small firms', Journal of Small Business Management, 40: 171-86.

Gibson, B., \& Casser, G. (2005). Longitudinal analysis of relationships between planning and performance in small firms. Small Business Economics, 25(3), 207-222.

Glaister K, Falshaw R. 1999. Strategic planning: still going strong? Long Range Planning 32 (1): 107-116.

Haake, K. (1987) Strategisches Verhalten in europäischen Klein- und Mittelunternehmen, Berlin: Duncker \& Humblot.

Jones, W. D. (1982). Characteristics of planning in small firms. Journal of Small Business Management, 20(3), 15-19.

Kropfberger, D. (1986) Erfolgsmanagement statt Krisenmanagement - Strategisches Management in Mittelbetrieben. Linz: Trauner.

Kupper, H.U. and Bronner, T. (1995) 'Strategische Ausrichtung mittelstandischer Unternehmungen', Internationales Gewerbearchiv, 43: 73-87.

Leitner, K.H. (2001). 'Strategisches Verhalten von kleinen und mittleren Unternehmungen. Eine empirische Untersuchung an österreichischen Industrieunternehmen vor einem 
industrieökonomischen und organisationstheoretischen Hintergrund', unpublished thesis, University of Vienna.

Matthews, C.H. and Scott, S.G. (1995) 'Uncertainty and planning in small and entrepreneurial firms: An empirical assessment', Journal of Small Business Management, 33(4): 34-52.

Mazzarol, T. (2003) 'The strategic management of small firms: Does the theory fit the practice?', University of Western Australia Discussion Paper, No. 0301.

Mazzarol, T. (2004). Strategic management of small firms: A proposed framework for entrepreneurial ventures. Paper presented at the 17th Annual SEAANZ Conference Entrepreneurship as the way of the future, Dated: 26-29 September, 2004, Brisbane, Queensland.

Naffziger, D. W. and Mueller, C. B. (1999). Strategic planning in small firms: activity and process reality. Journal of Small Business Strategy 10-1, 78-85.

O' Regan, N. and Ghobadian, A. (2000). Developing an exploratory model to determine the link between organizational culture, leadership style and contingency factors on the corporate strategy of manufacturing SMEs, International Journal of Manufacturing Technology and Management, Vol.2 No.1-7, 2000.

O'Regan, N., \& Ghobadian, A. (2004). Re-visiting the strategy-performance question: An empirical analysis. International Journal of Management and Decision Making, 5(2/3), 144-170.

O'Regan N. and Ghobadin A. (2007) “ Formal Strategic Planning: annual raindance or wheel of success?" Strategic Change, 16:11-22, 2007.

Pleitner, H. J. (1986) 'Strategisches Verhalten mittelstandischer Unternehmen', Internationales Gewerbearchiv, 34: 159-71.

Robinson, R.B. and Pearce, J.A. (1984) 'Research thrusts in small firm strategic planning', Academy of Management Review, 9: 128-37.

Scharpe, J. (1992) Strategisches Management im Mittelstand: Probleme der Implementierung und Ansatze zur Losung, Cologne: Eul.

Scholz, L. (1991) 'Strategische Unternehmensplanung in der deutschen Industrie: Bestandsaufnahme und kritische Bewertung', ifo Schnelldienst, 44(11): 17-25.

Schwenk, C.R. and Shrader, C.B. (1993) 'Effects of formal strategic planning on financial performance in small firms: A meta-analysis', Entrepreneurship: Theory and Practice, 17(3): 53-64.

Stonehouse, G., \& Pemberton, J. (2002). Strategic planning in SMEs - some empirical findings. Management Decision, 40(9), 853-861.

Vicere, A. A. (1995). Executive education and strategic imperatives: A formula for crafting competitiveness. American Journal of Management Development, 1(2), 31-36.

Wang, C., Walker, E. A. \& Redmond, J. (2006). Explaining the lack of strategic planning in SMEs: The importance of owner motivation. International Journal of Organisational Behaviour (in press). 